\title{
Effectiveness of acetamiprid in reducing rosy apple aphid population (Dysaphis plantaginea, Passerini) analysed in selected apple orchards
}

\author{
Skuteczność działania acetamiprydu w ograniczaniu populacji \\ mszycy jabłoniowo-babkowej (Dysaphis plantaginea, Passerini) \\ w wybranych sadach jabłoniowych
}

\author{
Michał Hołdaj*, Damian Gorzka, Grażyna Soika
}

\section{Summary}

The aim of the study was to evaluate the effectiveness of acetamiprid in the control of rosy apple aphid (Dysaphis plantaginea) originating from 6 apple orchards in Poland. The mortality of aphids treated with acetamiprid at the dosage of $0.2 \mathrm{~kg} / \mathrm{ha}$ was determined in laboratory conditions. As a result of the studies, reduced effectiveness of acetamiprid from 78.3 to $86.7 \%$ was noted for specimens of apple-tree aphid originating from four out of six examined apple orchards. High effectiveness of acetamiprid at the level of 89.7 to $95.3 \%$ was noted for the studied aphid populations in only two apple orchards. The obtained experimental results confirm a slight reduction in the effectiveness of acetamiprid in several populations of rosy apple aphid that may, but need not to be a result of resistance to this substance.

Key words: apple tree, aphids, neonicotinoides, effectiveness

\section{Streszczenie}

Celem badań była ocena skuteczności acetamiprydu w zwalczaniu mszycy jabłoniowo-babkowej (Dysaphis plantaginea) pochodzącej z różnych sadów na terenie kraju. Śmiertelność mszyc traktowanych acetamiprydem w dawce 0,2 kg/ha oceniono w warunkach laboratoryjnych. W wyniku przeprowadzonych badań stwierdzono obniżoną skuteczność acetamiprydu, która wynosiła od 78,3 do 86,7\% w zwalczaniu osobników mszycy jabłoniowo-babkowej pochodzących z czterech z sześciu badanych sadów jabłoniowych. Wysoką skuteczność acetamiprydu na poziomie od 89,7 do 95,3\% odnotowano dla populacji mszycy jabłoniowo-babkowej pochodzącej tylko z dwóch sadów jabłoniowych. Uzyskane wyniki doświadczeń potwierdzają niewielkie obniżenie skuteczności acetamiprydu w kilku populacjach mszycy jabłoniowo-babkowej, co może, ale nie musi być efektem odporności na tę substancję.

Słowa kluczowe: jabłoń, mszyce, neonikotynoidy, skuteczność

\section{Instytut Ogrodnictwa}

Konstytucji 3 Maja 1/3, 96-100 Skierniewice

*corresponding author: michal.holdaj@inhort.pl

ORCID: 0000-0003-1014-1475 


\section{Wstęp / Introduction}

Mszyca jabłoniowo-babkowa należy do najliczniejszych i najczęściej występujących mszyc w sadach jabłoniowych. Z analizy ankiet przeprowadzonych przez Instytut Ogrodnictwa w gospodarstwach sadowniczych zlokalizowanych na terenie całego kraju wynika, że mszyca ta występuje w 75,5\% sadów jabłoniowych (Hołdaj i wsp. 2009). Wieloletnie obserwacje własne wykonywane w sadach jabłoniowych wskazują, że w ostatnich latach mszyca jabłoniowo-babkowa nie żeruje już tylko na początku sezonu, aby później przenieść się na żywiciela wtórnego, jakim są różne gatunki babki (Plantago L.), lecz jej kolonie spotyka się coraz częściej, choć w mniejszej liczebności przez cały sezon, aż do późnej jesieni. Warto podkreślić, że główne szkody w postaci silnej deformacji owoców powstają w wyniku żerowania tej mszycy w okresie wczesno-wiosennym. Drobne, zniekształcone jabłka tworzące charakterystyczne grona, które pozostają na drzewach po opadzie czerwcowym nie mają ani wartości handlowej, ani konsumpcyjnej. W celu ograniczenia żerowania mszycy jabłoniowo-babkowej w 60\% sadów producenci wykonują trzy i więcej zabiegów, stosując przede wszystkim preparaty zawierające acetamipryd (grupa 4A według klasyfikacji IRAC), które na owady działają kontaktowo i żołądkowo, a na roślinie powierzchniowo, wgłębnie oraz systemicznie. Nierzadko również preparaty zawierające acetamipryd są stosowane przez sadowników także do zwalczania innych szkodników np. mszycy jabłoniowej (Aphis pomi De Geer), bawełnicy korówki (Eriosoma lanigerum Hausmann), owocnicy jabłkowej (Hoplocampa testudinea Klug), czy owocówki jabłkóweczki (Cydia pomonella L.).

Intensywne stosowanie chemicznych środków ochrony roślin oprócz niewątpliwych korzyści, jakimi są poprawa jakości i wielkości plonu niesie ze sobą także różne skutki uboczne (Olszak i Hurej 2011). Niewłaściwe stosowanie pestycydów skutkuje m.in. obecnością ich pozostałości w produktach, jak również może prowadzić do selekcji odpornych ras szkodników. Obniżona wrażliwość owadów i roztoczy na pestycydy stosowane do ich zwalczania pojawia się najszybciej u gatunków charakteryzujących się krótkim cyklem rozwojowym i rozwijających kilkanaście pokoleń w sezonie wegetacyjnym (Malinowski 2003). Zaistniała więc obawa, że tak duża liczba zabiegów w jednym sezonie wegetacyjnym preparatami opartymi na acetamiprydzie może powodować szybszą selekcję ras mszycy jabłoniowo-babkowej o obniżonej wrażliwości na tę substancję.

Celem podjętych badań była ocena skuteczności działania acetamiprydu zastosowanego $\mathrm{w}$ dawce $0,2 \mathrm{~kg} / \mathrm{ha}$ w ograniczeniu populacji mszycy jabłoniowo-babkowej pochodzących z produkcyjnych sadów jabłoniowych zlokalizowanych w różnych rejonach Polski.

\section{Materiały i metody / Materials and methods}

Badania prowadzono w latach 2013-2015. Materiał badawczy stanowiły bezskrzydłe samice i larwy mszycy jabłoniowo-babkowej z sześciu intensywnie chronionych sadów produkcyjnych zlokalizowanych w różnych rejonach kraju: Miłobądz - województwo pomorskie, Gorzyczki województwo wielkopolskie, Dąbrowice - województwo łódzkie, Grzymkowice - województwo łódzkie, Józefów nad Wisłą - województwo lubelskie, Michalczowa - województwo małopolskie oraz z sadu referencyjnego w Skierniewicach, w którym nie stosowano insektycydów od wielu lat. W wytypowanych sadach chronionych mszyca jabłoniowo-babkowa występowała rokrocznie w dużym nasileniu, pomimo wykonywanych zabiegów zwalczających. Populacja mszycy jabłoniowo-bakowej ze Skierniewic (na podstawie wcześniejszych doświadczeń) była określona jako wrażliwa na acetamipryd. Kolonie mszycy jabłoniowo-babkowej zebrane $\mathrm{z}$ poszczególnych lokalizacji, aby zapobiec mieszaniu się populacji między sobą, umieszczane były w oddzielnych izolatorach. Hodowla mszyc była prowadzona w stałej temperaturze $25^{\circ} \mathrm{C}$, naświetleniu $16: 8$ (dzień/noc) oraz wilgotności około 50-60\%. Mszyce pobrane bezpośrednio z sadów oraz $\mathrm{z}$ hodowli poddawano testom przeżywalności z użyciem acetamiprydu (Mospilan $20 \mathrm{SP}$ ) w dawce 0,2 kg/ha.

Doświadczenia z aplikacją acetamiprydu przeprowadzono w specjalnie do tego celu przygotowanych wentylowanych klateczkach. Na krążki bibuły filtracyjnej o średnicy $5 \mathrm{~cm}$ nasączone roztworem insektycydu w zalecanej dawce $0,2 \mathrm{~kg} / \mathrm{ha}$ (tak, aby były wilgotne, ale nie mokre) nakładano pędzelkiem po 15 mszyc i umieszczano w klateczce o tej samej średnicy. Klateczki przetrzymywano w kamerze hodowlanej ze stałą temperaturą $-26^{\circ} \mathrm{C}$, wilgotnością $-55 \%$ i naświetleniem $16: 8$. Mszyce z każdej populacji (osobno samice bezskrzydłe i larwy) testowano w 4 powtórzeniach. Śmiertelność mszyc kontrolowano po 4, 24 i 48 godzinach od momentu założenia doświadczenia. Liczono żywe i martwe osobniki. Kontrolę dla doświadczenia stanowiły mszyce z poszczególnych lokalizacji naniesione na bibułę filtracyjną nasączoną wodą destylowaną. W każdym roku badań, doświadczenie powtarzano pięciokrotnie testując po 300 larw i 300 samic bezskrzydłych. Łącznie w ciągu trzech lat przebadano 14400 osobników. Procentową śmiertelność mszyc wyrażono za pomocą wzoru Abbotta.

Wyniki opracowano statystycznie za pomocą analizy wariancji (ANOVA). Istotność różnic pomiędzy średnimi oceniono za pomocą testu Newmana-Keulsa przy poziomie istotności $\mathrm{p}=0,05$. Analizy przeprowadzono $\mathrm{w}$ programie STATISTICA v. 13.3.

\section{Wyniki i dyskusja / Results and discussion}

Wyniki badań wykazały zróżnicowaną skuteczność acetamiprydu $\mathrm{w}$ redukcji osobników mszycy jabłoniowo- 
-babkowej pochodzących z sadów jabłoniowych zlokalizowanych w różnych rejonach Polski. W czterech spośród sześciu badanych sadów jabłoniowych, skuteczność zwalczania mszycy jabłoniowo-bakowej była poniżej 90\% i wy- nosiła od 78,3 do 86,7\%. W miejscowościach Dąbrowice i Michalczowa w 2015 roku efektywność acetamiprydu w zwalczaniu larw tej mszycy była najniższa i wyniosła odpowiednio 78,3\% i 79,0\%. Wysoką śmiertelność po za-

Tabela1. Liczba żywych mszyc i skuteczność działania acetamiprydu na mszycę jabłoniowo-babkową (Dysaphis plantaginea) po 48 godzinach od momentu założenia doświadczenia

Table 1. Number of live individuals and effectiveness of acetamiprid on rosy apple aphids (Dysaphis plantaginea) in $48 \mathrm{~h}$ after the begin of the experience

\begin{tabular}{|c|c|c|c|c|c|c|c|}
\hline \multirow[b]{2}{*}{$\begin{array}{l}\text { Lokalizacja } \\
\text { Location }\end{array}$} & \multirow[b]{2}{*}{$\begin{array}{l}\text { Acetamipryd } \\
\text { Acetamiprid }\end{array}$} & \multicolumn{2}{|c|}{2013} & \multicolumn{2}{|l|}{2014} & \multicolumn{2}{|c|}{2015} \\
\hline & & $\begin{array}{c}\text { samice } \\
\text { bezskrzydłe } \\
\text { wingless female }\end{array}$ & $\begin{array}{l}\text { larwy } \\
\text { larvae }\end{array}$ & $\begin{array}{c}\text { samice } \\
\text { bezskrzydłe } \\
\text { wingless female }\end{array}$ & $\begin{array}{l}\text { larwy } \\
\text { larvae }\end{array}$ & \begin{tabular}{|c|} 
samice \\
bezskrzydłe \\
wingless female
\end{tabular} & $\begin{array}{l}\text { larwy } \\
\text { larvae }\end{array}$ \\
\hline \multicolumn{8}{|c|}{ Liczba żywych osobników/1 doświadczenie - Number of live individuals/1 treatment } \\
\hline \multirow{2}{*}{ Dąbrowice } & $\begin{array}{l}\text { traktowane } \\
\text { treated }\end{array}$ & $9,0 \mathrm{c}$ & $9,2 \mathrm{c}$ & $9,0 \mathrm{c}$ & $10,4 \mathrm{~b}$ & $9,0 \mathrm{c}$ & $13,0 \mathrm{~b}$ \\
\hline & $\begin{array}{l}\text { nietraktowane } \\
\text { untreated }\end{array}$ & $60,0 \mathrm{a}$ & $59,8 \mathrm{a}$ & $60,0 \mathrm{a}$ & $60,0 \mathrm{a}$ & $60,0 \mathrm{a}$ & $60,0 \mathrm{a}$ \\
\hline \multirow{2}{*}{ Grzymkowice } & $\begin{array}{l}\text { traktowane } \\
\text { treated }\end{array}$ & $8,0 \mathrm{c}$ & $8,2 \mathrm{c}$ & $8,0 \mathrm{c}$ & $10,4 \mathrm{~b}$ & $8,0 \mathrm{c}$ & $9,4 \mathrm{c}$ \\
\hline & $\begin{array}{l}\text { nietraktowane } \\
\text { untreated }\end{array}$ & $59,8 \mathrm{a}$ & $60,0 \mathrm{a}$ & $60,0 \mathrm{a}$ & $60,0 \mathrm{a}$ & $60,0 \mathrm{a}$ & $59,8 \mathrm{a}$ \\
\hline \multirow{2}{*}{ Gorzyczki } & $\begin{array}{l}\text { traktowane } \\
\text { treated }\end{array}$ & $10,8 \mathrm{~b}$ & $10,6 \mathrm{~b}$ & $10,8 \mathrm{~b}$ & $10,0 \mathrm{~b}$ & $10,0 \mathrm{~b}$ & $9,4 \mathrm{c}$ \\
\hline & $\begin{array}{l}\text { nietraktowane } \\
\text { untreated }\end{array}$ & 59,8 a & $60,0 \mathrm{a}$ & $60,0 \mathrm{a}$ & $60,0 \mathrm{a}$ & $60,0 \mathrm{a}$ & $60,0 \mathrm{a}$ \\
\hline \multirow{2}{*}{ Michalczowa } & $\begin{array}{l}\text { traktowane } \\
\text { treated }\end{array}$ & $11,2 \mathrm{~b}$ & $11,0 \mathrm{~b}$ & $11,2 \mathrm{~b}$ & $10,6 \mathrm{~b}$ & $11,8 \mathrm{~b}$ & $12,6 \mathrm{~b}$ \\
\hline & $\begin{array}{l}\text { nietraktowane } \\
\text { untreated }\end{array}$ & $59,8 \mathrm{a}$ & $59,8 \mathrm{a}$ & $60,0 \mathrm{a}$ & $60,0 \mathrm{a}$ & $60,0 \mathrm{a}$ & $60,0 \mathrm{a}$ \\
\hline \multirow{2}{*}{ Miłobądz } & $\begin{array}{l}\text { traktowane } \\
\text { treated }\end{array}$ & $5,2 \mathrm{~d}$ & $4,8 \mathrm{~d}$ & $5,2 \mathrm{~d}$ & $6,2 \mathrm{~d}$ & $5,8 \mathrm{~d}$ & $6,0 \mathrm{~d}$ \\
\hline & $\begin{array}{l}\text { nietraktowane } \\
\text { untreated }\end{array}$ & $59,8 \mathrm{a}$ & $60,0 \mathrm{a}$ & $60,0 \mathrm{a}$ & $60,0 \mathrm{a}$ & $60,0 \mathrm{a}$ & $59,6 \mathrm{a}$ \\
\hline \multirow{2}{*}{$\begin{array}{l}\text { Józefów } \\
\text { nad Wisłą }\end{array}$} & \begin{tabular}{|l} 
traktowane \\
treated
\end{tabular} & $5,0 \mathrm{~d}$ & $5,0 \mathrm{~d}$ & $4,6 \mathrm{~d}$ & $5,4 \mathrm{~d}$ & $4,6 \mathrm{~d}$ & $2,8 \mathrm{~d}$ \\
\hline & \begin{tabular}{|l} 
nietraktowane \\
untreated
\end{tabular} & $60,0 \mathrm{a}$ & $59,8 \mathrm{a}$ & $60,0 \mathrm{a}$ & $60,0 \mathrm{a}$ & $60,0 \mathrm{a}$ & $60,0 \mathrm{a}$ \\
\hline \multirow{2}{*}{$\begin{array}{l}\text { Skierniewice } \\
\text { rasa wrażliwa } \\
\text { sensitive variety }\end{array}$} & $\begin{array}{l}\text { traktowane } \\
\text { treated }\end{array}$ & $0,4 \mathrm{f}$ & $0,4 \mathrm{f}$ & $0,4 \mathrm{f}$ & $0,4 \mathrm{f}$ & $0,0 \mathrm{f}$ & $0,2 \mathrm{f}$ \\
\hline & $\begin{array}{l}\text { nietraktowane } \\
\text { untreated }\end{array}$ & $60,0 \mathrm{a}$ & $59,8 \mathrm{a}$ & $60,0 \mathrm{a}$ & $60,0 \mathrm{a}$ & $60,0 \mathrm{a}$ & $59,8 \mathrm{a}$ \\
\hline \multicolumn{2}{|c|}{ Lokalizacja - Location } & \multicolumn{6}{|c|}{ Skuteczność według wzoru Abbotta [\%] - Efficacy according to Abbott formula [\%] } \\
\hline \multicolumn{2}{|l|}{ Dąbrowice } & 85,0 & 84,6 & 85,0 & 82,7 & 85,0 & 78,3 \\
\hline \multicolumn{2}{|l|}{ Grzymkowice } & 86,6 & 86,3 & 86,7 & 82,7 & 86,7 & 84,3 \\
\hline \multicolumn{2}{|l|}{ Gorzyczki } & 81,9 & 82,3 & 82,0 & 83,3 & 83,3 & 84,3 \\
\hline \multicolumn{2}{|l|}{ Michalczowa } & 81,3 & 81,6 & 81,3 & 82,3 & 80,3 & 79,0 \\
\hline \multicolumn{2}{|l|}{ Miłobądz } & 91,3 & 92,0 & 91,3 & 89,7 & 90,3 & 89,9 \\
\hline \multicolumn{2}{|c|}{ Józefów nad Wisłą } & 91,7 & 91,6 & 92,3 & 91,0 & 92,3 & 95,3 \\
\hline \multicolumn{2}{|c|}{$\begin{array}{l}\text { Skierniewice } \\
\text { rasa wrażliwa - sensitive variety }\end{array}$} & 99,3 & 99,3 & 99,3 & 99,3 & 100,0 & 99,7 \\
\hline
\end{tabular}

Średnie w kolumnie oznaczone tą samą literą nie różnią się między sobą przy poziomie istotności 0,05 (według testu Newmana-Keulsa) The means in the column marked with the same letter do not differ at a significance level of 0.05 (according to the Newman-Keuls test) 
Tabela 2. Liczebność samic bezskrzydłych i larw mszycy jabłoniowo-babkowej w poszczególnych sadach jabłoniowych Table 2. Number of rosy apple aphids wingless female and larvae individuals in individual apple orchards

\begin{tabular}{|c|c|c|c|c|c|c|}
\hline \multirow{3}{*}{$\begin{array}{l}\text { Lokalizacja } \\
\text { Location }\end{array}$} & \multicolumn{6}{|c|}{ Liczba żywych osobników/1 doświadczenie - Number of live individuals/1 treatment } \\
\hline & \multicolumn{2}{|c|}{2013} & \multicolumn{2}{|c|}{2014} & \multicolumn{2}{|c|}{2015} \\
\hline & $\begin{array}{c}\text { samice } \\
\text { bezskrzydłe } \\
\text { wingless female }\end{array}$ & $\begin{array}{l}\text { larwy } \\
\text { larvae }\end{array}$ & $\begin{array}{c}\text { samice } \\
\text { bezskrzydłe } \\
\text { wingless female }\end{array}$ & $\begin{array}{l}\text { larwy } \\
\text { larvae }\end{array}$ & $\begin{array}{c}\text { samice } \\
\text { bezskrzydłe } \\
\text { wingless female }\end{array}$ & $\begin{array}{l}\text { larwy } \\
\text { larvae }\end{array}$ \\
\hline Dąbrowice & $9,0 \mathrm{a}$ & $9,2 \mathrm{a}$ & $9,0 \mathrm{a}$ & $10,4 \mathrm{a}$ & $9,0 \mathrm{a}$ & $13,0 \mathrm{a}$ \\
\hline Grzymkowice & $8,0 \mathrm{a}$ & $8,2 \mathrm{a}$ & $8,0 \mathrm{a}$ & $10,4 \mathrm{a}$ & $8,0 \mathrm{a}$ & $9,4 \mathrm{a}$ \\
\hline Gorzyczki & $10,8 \mathrm{a}$ & $10,6 \mathrm{a}$ & $10,8 \mathrm{a}$ & $10,0 \mathrm{a}$ & $10,0 \mathrm{a}$ & $9,4 \mathrm{a}$ \\
\hline Michalczowa & $11,2 \mathrm{a}$ & $11,0 \mathrm{a}$ & $11,2 \mathrm{a}$ & $10,6 \mathrm{a}$ & $11,8 \mathrm{a}$ & $12,6 \mathrm{a}$ \\
\hline Miłobądz & $5,2 \mathrm{a}$ & $4,8 \mathrm{a}$ & $5,2 \mathrm{a}$ & $6,2 \mathrm{a}$ & $5,8 \mathrm{a}$ & $6,0 \mathrm{a}$ \\
\hline Józefów nad Wisłą & $5,0 \mathrm{a}$ & $5,0 \mathrm{a}$ & $4,6 \mathrm{a}$ & $5,4 \mathrm{a}$ & $4,6 \mathrm{a}$ & $2,8 \mathrm{a}$ \\
\hline $\begin{array}{l}\text { Skierniewice } \\
\text { rasa wrażliwa - sensitive variety }\end{array}$ & $0,4 \mathrm{a}$ & $0,4 \mathrm{a}$ & $0,4 \mathrm{a}$ & $0,4 \mathrm{a}$ & $0,0 \mathrm{a}$ & $0,2 \mathrm{a}$ \\
\hline
\end{tabular}

Średnie w wierszu oznaczone tą samą literą nie różnią się między sobą przy poziomie istotności 0,05 (według testu Newmana-Keulsa)

The means in the row marked with the same letter do not differ at a significance level of 0.05 (according to the Newman-Keuls test)

stosowaniu acetamiprydu, która kształtowała się na poziomie 89,7-95,3\% (tab. 1) stwierdzono u osobników mszycy jabłoniowo-babkowej pochodzących z sadów położonych w miejscowościach: Józefów nad Wisłą i Miłobądz. Podczas badań nie wykazano statystycznie istotnych różnic w skuteczności acetamiprydu w odniesieniu do samic bezskrzydłych i larw mszycy jabłoniowo-babkowej porównywanej w danym roku i w danej lokalizacji (tab. 2).

W dostępnej literaturze nie znaleziono danych na temat wrażliwości mszycy jabłoniowo-bakowej na substancje czynne insektycydów. Wykazano ją natomiast między innymi u mszycy brzoskwiniowej (Myzus persicae Sulzer). Stwierdzono, że mszyca ta rozwinęła odporność na co najmniej siedemdziesiąt różnych syntetycznych związków (Devonshire i wsp. 1998), w tym na acetamipryd i tiachlopryd z grupy neonikotynoidów (Nauen i wsp. 2001; Tomizawa i Casida 2003, 2005; Nauen i Denholm 2005; Panini i wsp. 2013). Istniejące doniesienia literaturowe wskazują, iż osobniki naturalnie uodpornione na stosowane do ich zwalczania insektycydy występują u wielu gatunków owadów i roztoczy. Zjawisko to zaobserwowano między innymi u słodyszka rzepakowego (Meligethes aeneus Fabricius) (Mrówczyński i wsp. 2009; Węgorek 2009) i chowacza podobnika (Ceutorhynchus assimilis Paykull.), znanych w Polsce jako groźne szkodniki rzepaku (Zamojska i Węgorek 2014), czy stonki ziemniaczanej (Leptinotarsa decemlineata Say) (Węgorek 2005; Zamojska i wsp. 2011).

Selekcja osobników mniej wrażliwych na środki ochrony roślin stosowane w sadach ma miejsce przede wszystkim u gatunków szkodników bardzo płodnych i rozwijających kilka lub kilkanaście pokoleń w sezonie wegetacyjnym, jak przędziorek chmielowiec (Gorzka i wsp. 2014). Dotychczasowe obserwacje wskazują, że z sadów zlokalizowanych w Dąbrowicach i Michalczowej przeżywało nawet kolejno $21,0 \%$ i $21,7 \%$ populacji szkodnika. Biorąc pod uwagę wysoką zdolność reprodukcyjną mszyc, takie wyniki mogą sugerować, że pewna frakcja populacji mszycy jabłoniowo-babkowej mogła wytworzyć mechanizmy detoksyfikacji acetamiprydu. Obniżoną skuteczność acetamiprydu na poziomie $82 \%$ zaobserwowano już wcześniej także w odniesieniu do mszycy jabłoniowej (Aphis pomi) (Hołdaj i wsp. 2012). Dlatego bardzo ważne jest zastosowanie odpowiedniej strategii zwalczania oraz zapobieganie powstawaniu zjawiska odporności u szkodników (Węgorek i wsp. 2009; Olszak i Hurej 2011).

Metodą zalecaną w integrowanej ochronie roślin, która pozwala na redukcję zjawiska odporności u owadów na stosowane środki ochrony roślin jest rotacja substancji czynnych o różnych mechanizmach działania (Węgorek 1994; Clarke i wsp. 1997; Zamojska i wsp. 2011). Należy tu wspomnieć, że bardzo często przyczyną niskiej skuteczności insektycydów może być także niedostosowanie się do zaleceń producenta środka ochrony, które są szczegółowo opisane w etykiecie-instrukcji. Podczas aplikacji preparatów ważne są zarówno odpowiednie warunki atmosferyczne (temperatura, wiatr, wilgotność, nasłonecznienie), dawka użytego środka (w 1/ha lub kg/ha), jak też termin zabiegu, dokładność jego wykonania, ilość cieczy roboczej zużytej na hektar oraz stadium rozwojowe owada. Istotny wpływ ma również wielkość drzew, zagęszczenie koron oraz mechanizm działania preparatu (powierzchniowe, układowe, wgłębne) (Olszak i wsp. 2000). Przedstawione w pracy wyniki doświadczeń nie świadczą o odporności mszycy jabłoniowo-babkowej na acetamipryd. Potwierdzają niewielkie obniżenie skuteczności acetamiprydu w kilku populacjach, co może, ale nie musi być efektem odporności na tę substancję czynną. 


\section{Wnioski / Conclusions}

1. Obniżoną skuteczność acetamiprydu w ograniczaniu populacji mszycy jabłoniowo-babkowej stwierdzono w czterech spośród sześciu badanych sadów jabłoniowych na terenie Polski.

2. W trakcie prowadzonych badań nie odnotowano istotnych statystycznie różnic w skuteczności acetamiprydu w odniesieniu do larw i samic bezskrzydłych mszycy jabłoniowo-babkowej pochodzących $\mathrm{z}$ tych samych sadów.
3. Wykazane różnice w skuteczności działania acetamiprydu w odniesieniu do mszycy jabłoniowo-babkowej w różnych sadach jabłoniowych wskazują na konieczność stałego monitorowania zjawiska i na tej podstawie opracowania strategii jej zwalczania.

W pracy wykorzystano wyniki badań uzyskane podczas realizacji tematu statutowego „Monitoring występowania odporności mszycy jabłoniowo-babkowej Dysaphis plantaginea (Passerini) (Homoptera: Aphididae) na wybrane insektycydy w sadach jabłoniowych".

\section{Literatura / References}

Clarke J.H., Clark W.S., Hancock M. 1997. Strategies for prevention of development of pesticide resistance in the UK - lessons for and from the use of herbicides, fungicides and insecticides. Pesticide Science 51 (3): 391-397. DOI: 10.1002/(SICI)1096-9063(199711)51:3<391::AID-PS654>3.0.CO;2-M

Devonshire A.L., Field L.M., Foster S.P., Moores G.D., Williamson M.S., Blackman R.L. 1998. The evolution of insecticide resistance in the peach-potato aphid, Myzus persicae. Philosophical Transactions of the Royal Society B: Biological Sciences 353 (1376): 1677-1684. DOI: 10.1098/rstb.1998.0318

Gorzka D., Hołdaj M., Olszak R.W. 2014. Odporność przędziorka chmielowca (Tetranychus urticae, Koch) na METI akarycydy analizowana w wybranych sadach jabłoniowych w Polsce. [Two spotted spider mite (Tetranychus urticae, Koch) resistance to METI acaricides analysed in selected Polish apple orchards]. Progress in Plant Protection 54 (3): 304-307. DOI: 10.14199/ppp-2014-049

Hołdaj M., Olszak R.W., Gorzka D. 2009. Ocena zagrożenia i problemów zwalczania mszyc sadów jabłoniowych (badania ankietowe). W: Materiały Konferencyjne 53. Ogólnopolska Konferencja Ochrony Roślin Sadowniczych. Ossa, 18-19 lutego 2009: 104-110.

Hołdaj M., Olszak R.W., Gorzka D. 2012. Badanie skuteczności najczęściej stosowanych aficydów w walce z mszycą jabłoniową (Aphis pomi De Geer, Aphididae, Homoptera) w uprawach jabłoni na terenie Polski. [Study on the effectiveness of insecticides applied to eliminate green apple aphid (Aphis pomi De Geer, Aphididae, Homoptera) in apple cultivation in Poland]. Progress in Plant Protection /Postępy w Ochronie Roślin 52 (2): 226-228. DOI: 10.14199/ppp-2012-039

Malinowski H. 2003. Odporność owadów na insektycydy. Mechanizmy powstawania i możliwości przeciwdziałania. Wieś Jutra, Warszawa, 211 ss.

Mrówczyński M., Węgorek P., Zamojska J., Pruszyński G., Wachowiak H. 2009. Porównanie wyników badań polowych i laboratoryjnych nad odpornością słodyszka rzepakowego (Meligethes aeneus F.) w Polsce. [Comparison of the results of laboratory and field studies concerning pollen beetle (Meligethes aeneus F.) resistance to insecticides in Poland]. Progress in Plant Protection/Postępy w Ochronie Roślin 49 (3): 1205-1210.

Nauen R., Denholm I. 2005. Resistance of insect pests to neonicotinoid insecticides: Current status and future prospects. Archives of Insect Biochemistry and Physiology 58 (4): 200-215. DOI: 10.1002/arch.20043

Nauen R., Ebbinghaus-Kintscher U., Elbert A., Jeschke P., Tietjen K. 2001. Acetylcholine receptors as sites for developing neonicotinoid insecticides. s. 77-105. W: Biochemical Sites of Insecticide Action and Resistance (I. Ishaaya, red.). Springer-Verlag, Berlin, Heidelberg, 343 ss. ISBN 978-3-540-67625-6. DOI: 10.1007/978-3-642-59549-3

Olszak R.W., Hurej M. 2011. Odporność szkodników na insektycydy - zagrożenia i sposoby minimalizowania problemu. W: Materiały Konferencyjne „60-lecie IOR - PIB oraz przyszłość integrowanej ochrony roślin w Polsce”. 51. Sesja Naukowa Instytutu Ochrony Roślin - Państwowego Instytutu Badawczego. Poznań, 17-18 lutego 2011, 46 ss.

Olszak R.W., Pruszyński S., Lipa J.J., Dąbrowski Z.T. 2000. Rozwój koncepcji i strategii wykorzystania metod oraz środków ochrony roślin. Progress in Plant Protection/Postępy w Ochronie Roślin 40 (1): 40-50.

Panini M., Dradi D., Marani G., Butturini A., Mazzoni E. 2013. Detecting the presence of target-site resistance to neonicotinoids and pyrethroids in Italian populations of Myzus persicae. Pest Management Science 70 (6): 931-938. DOI: 10.1002/ps.3630

Tomizawa M., Casida J.E. 2003. Selective toxicity of neonicotinoids attributable to specificity of insect and mammalian nicotinic receptors. Annual Review of Entomology 48: 339-364. DOI: 10.1146/annurev.ento.48.091801.112731

Tomizawa M., Casida J.E. 2005. Neonicotinoid insecticide toxicology: mechanisms of selective action. Annual Review of Pharmacology and Toxicology 45: 247-268. DOI: 10.1146/annurev.pharmtox.45.120403.095930

Węgorek P. 1994. Poziom wrażliwości wybranych populacji stonki ziemniaczanej (Leptinotarsa decemlineata Say.) z Wielkopolski na deltametrynę i chlorfenwinfos w latach 1992 i 1993. W: Materiały Konferencyjne 34. Sesja Naukowa Instytutu Ochrony Roślin, część 2: $233-236$

Węgorek P. 2005. Current status of resistance in Colorado potato beetle (Leptinotarsa decemlineata Say) to selected active substances of insecticides in Poland. [Aktualny stan odporności stonki ziemniaczanej (Leptinotarsa decemlineata Say) na wybrane substancje aktywne środków chemicznych zalecanych w Polsce do jej zwalczania]. Journal of Plant Protection Research 45 (4): 309-319.

Węgorek P. 2009. Badania nad odpornością chrząszczy słodyszka rzepakowego (Meligethes aeneus F.) na insektycydy. Rozprawy Naukowe Instytut Ochrony Roślin - Państwowy Instytut Badawczy, Zeszyt 20, 123 ss.

Węgorek P., Mrówczyński M., Zamojska J. 2009. Strategia zapobiegania odporności słodyszka rzepakowego w Polsce. Instytut Ochrony Roślin - Państwowy Instytut Badawczy, Poznań, 8 ss. 
Zamojska J., Węgorek P. 2014. Preliminary studies on the susceptibility level of Ceutorchynhus assimilis (Coleoptera: Curculionidae) to acetamiprid and chlorpyrifos in Poland and resistance mechanisms of the pest to acetamiprid. Journal of Insect Science 14 (265): 1-6. DOI: $10.1093 /$ jisesa/ieu127

Zamojska J., Węgorek P., Mrówczyński M. 2011. Changes in the Colorado potato beetle (Leptinotarsa decemlineata Say) susceptibility level to pyrethroids and the pest resistance mechanisms to deltamethrin. [Zmiany we wrażliwości stonki ziemniaczanej (Leptinotarsa decemlineata Say) na pyretroidy i mechanizmy odporności szkodnika na deltametrynę]. Journal of Plant Protection Research 51 (3): 294-299. DOI: 10.2478/v10045-011-0048-2 